\title{
Self-report measures as complementary exams in the diagnosis of insomnia
}

\section{Medidas de autorresposta como exames complementares no diagnóstico de insónia}

\author{
Daniel Ruivo Marques (1,2) \\ (1) Univ Aveiro, Portugal \\ (2) Univ Coimbra, CINEICC, FPCEUC, Portugal
}

Received: 03/12/2019; Reviewed: 14/12/2019; Accepted: 17/12/2019.

https://doi.org/10.31211/rpics.2020.6.1.161

Chronic insomnia disorder (CID) is a highly prevalent sleep disorder and a public health problem (Riemann et al., 2017). It is well recognized as a subjective disorder. Subjective because the diagnosis is fundamentally based on the self-report/complaints of the patients and in the clinical assessment of the sleep expert through a systematic clinical interview - which is the standard method (gold standard) for establishing a diagnosis of CID (Marques et al., 2018). On the contrary, diagnosis of other sleep disorders demands the so-called objective measures such as polysomnography (PSG) (Riemann et al., 2017). We cannot forget that being CID a subjective disorder, it is important to be exhaustive in clinical assessment. In sleep medicine field, there are some questionnaires that are extensively used in insomnia both in research and clinical settings such as the Pittsburgh Sleep Quality Index, the Insomnia Severity Index, the Glasgow Sleep Effort Scale, the Dysfunctional Beliefs and Attitudes about Sleep, among many others (Spielman et al., 2011). The development of psychological assessment tools is an area where psychologists make an important contribution. Even when the scales are not validated into the appropriate Languages, mere translation may be an essential clinical technique in intervention programs. Of course, when we have appropriate validations with representative samples, we can interpret the results of our patients contributing to quantitative evaluation, beyond the qualitative one (Marques et al., 2018).

Despite this germane utilization of self-report measures in insomnia, we should assume that our knowledge of these measures is insufficient (with some exceptions). Most of the instruments are validated in a small number

\section{DI\&D | ISMT}

rpics@ismt.pt https://rpics.ismt.pt
Publicação em Acesso Aberto

(C)2020. O(s) Autor(es). Este é um artigo de acesso aberto distribuído sob a Licença Creative Commons Attribution, que permite uso, distribuição e reprodução sem restrições em qualquer meio, desde que o trabalho original seja devidamente citado.
Daniel Ruivo Marques University of Aveiro, Department of Education and Psychology Campus Universitário de Santiago 3810-193 Aveiro, Portugal Email:drmarques@ua.pt 
of countries comprising most of the times limited sample sizes (Marques \& Azevedo, 2018). Besides, new psychometric methods such as item response theory and network analysis have been rarely explored with these tools (Marques \& Azevedo, 2018). On the other hand, meta-analyses on reliability indexes - reliability generalization studies - are lacking (Rodriguez \& Maeda, 2006).

In summarizing, self-report measures constitute an important tool in the assessment and therapy of CID. We can even say that they constitute complementary exams in the diagnosis of insomnia, where dysfunctional cognitions and maladaptive behaviors are so crucial. At the current moment, we think that researchers and clinicians should be more concerned about refining the existing measures than trying to propose new ones.

Conflict of interest | Conflito de interesses: nenhum | none.

Funding sources | Fontes de financiamento: nenhuma | none.

\section{References}

Marques, D., \& Azevedo, M. H. (2018). Potentialities of network analysis for sleep medicine. Journal of Psychosomatic Research, 111, 89-90. https://doi.org/10.1016/j.jpsychores.2018.05.019

Marques, D., Clemente, V., Gomes, A., \& Azevedo, M. H. (2018). Profiling insomnia using subjective measures: Where are we and where are we going. Sleep Medicine, 42, 103-104. https://doi.org/10.1016/j.sleep.2017.12.006

Riemann, D., Baglioni, C., Bassetti, C., Bjorvatn, B., Groselj, L. D., Ellis, J. G., Espie, C. A., Garcia-Borreguero, D., Gjerstad, M., Gonçalves, M., Hertenstein, E., Jansson-Fröjmark, M., Jennum, P. J., Leger, D., Nissen, C., Parrino, L., Paunio, T., Pevernagie, D., Verbraecken, J., ... Spiegelhalder, K. (2017). European guideline for the diagnosis and treatment of insomnia. Journal of Sleep Research, 26(6), 675-700. https://doi.org/10.1111/jsr.12594

Rodriguez, M., \& Maeda, Y. (2006). Meta-analysis of coefficient alpha. Psychological Methods, 11(3), $306-322$. https://doi.org/10.1037/1082-989X.11.3.306

Spielman, A., Yang, C.-M., \& Glovinsky, P. (2011). Assessment techniques for insomnia. In M. Kryger, T. Roth, \& W. Dement (Eds.), Principles and practice of sleep medicine (5th ed., pp. 850-865). Elsevier Saunders. 